\title{
Hazel Rowley: Obituary
}

\author{
Patrick Hutchings
}

Published online: 23 June 2011

(C) Springer Science+Business Media B.V. 2011

The untimely death of Hazel Rowley at the age of 59 is a great loss to the world of letters, and to her friends. She died in New York where she latterly spent much of her time since circa 2003. She was a colleague of the Sophia editors at Deakin University. While there she completed the first of her notable biographies, that on Christina Stead: one recalls the launch of this splendid book at a fashionable restaurant in Melbourne. Rowley left Deakin and Australia with memorable parting messages: she found the Literary programme at Deakin too theory-laden and said so; and her view of the then Labor government's University 'Reforms' formed part of her farewell interview with the newspaper The Australian ('Universities are losing on points', December, 1996). In it she was scathing, expressing her - low - opinion of the then Minister of Education. Abandoning the slowly collapsing academia she went abroad to pursue her true vocation as a biographer. While on a writing fellowship at Harvard she wrote on the leftist African-American author Richard Wright. This was followed by Tête-à-Tête: The tumultuous lives and loves of Simone de Beauvoir and Jean-Paul Sartre. Copyright issues saw one printing of this book pulped, but a revised issue came out to great acclaim. Rowley, who was fluent in French - had earlier met and talked with de Beauvoir, so she knew - half of - her biographical subject rather well. Her last book, on Franklin Delano and Eleanor Roosevelt, was fairly recently launched, and very well received. In New York, Rowley met often with Sophia's chief editor Purushottama Bilimoria, who, without quite abandoning Deakin and Melbourne, sensibly contrives to spend much of his year at various American universities and at Oxford. Rowley was born in London and brought to Adelaide as a child. She - as one recalls - never became reconciled with her new country. Her memorial service was held on 13 March 2011 at the elegant, Gothic Revival, Episcopalian Church of the Transfiguration in New York City.

\section{VALE}

P. Hutchings $(\square)$

School of Philosophy, Anthropology and Social Inquiry, University of Melbourne, Parkville, Victoria 3010, Australia

e-mail: sophia@philosophy.unimelb.edu.au 